\title{
People, Planet, and Profit: A Bibliometric Analysis of Triple Bottom Line Theory
}

\author{
Thiago Henrique Martins Pereira ${ }^{1} \&$ Henrique Cordeiro Martins ${ }^{1}$ \\ ${ }^{1}$ FUMEC University, Belo Horizonte, Brazil \\ Correspondence: Thiago Henrique Martins Pereira, Doctoral and master's Program in Administration (PDMA) at \\ FUMEC University - Faculty of Business Sciences - FACE. Av. Afonso Pena, $n^{\circ} 3880$ - 1st floor - B. Cruzeiro - \\ Belo Horizonte / Minas Gerais. CEP: 30.130-009, Brazil. E-mail: tigoemtv@hotmail.com
}

$\begin{aligned} & \text { Received: December 22, } 2020 \quad \text { Accepted: January 23, } 2021 \quad \text { Online Published: January 26, } 2021 \\ & \text { doi:10.5539/jms.v11n1p64 }\end{aligned}$ URL: https://doi.org/10.5539/jms.v11n1p64

\begin{abstract}
Scientific production on Triple Bottom Line Theory is, recently, attracting attention in the literature. A series of factors are related to this interest, among them: (i) the scarcity of productive resources; and, (ii) the need to optimize processes not only in economic terms, but especially in their environmental and social aspects. These factors have fostered the study of sustainability models. Therefore, the present study aims to conduct a bibliometric investigation into Triple Bottom Line Theory. To this end, an analysis of 1386 publications, published between 1999 and 2020, indexed in the Web of Science database, was developed. Additionally, the present article describes in detail the main contributors to the academic debate on this topic. Furthermore, it highlights the relevant areas of research at the present time. It was found that the search for models to assess environmental, economic and social performance is highly relevant today. It was also found that, among the main models used for this purpose, the class of Data Envelopment Analysis models stands out.
\end{abstract}

Keywords: triple bottom line, sustainability, bibliometrics

\section{Introduction}

The scarcity of natural and environmental resources, characterized by the growing demand for raw materials from global supply chains, has led countries to intensify the design of sustainable policies. In this context, both public entities and private organizations are being encouraged to rethink their practices to increase the environmental, economic and social efficiency of their processes. Given this scarcity of resources, sustainability assumes a prominent place and can even differentiate the increase of competitiveness in the international market (Matopoulos et al., 2015; De Carvalho et al., 2020; He et al., 2020; Lowitt, 2011).

The concept of sustainability comes from ecology and describes a natural, regenerative system: that is, one that maintains its basic properties over time to satisfy a given population, replenishing itself continuously (Zhou et al., 2018). Sustainability can be defined as the degree of resilience of systems and processes (Chofreh et al., 2015). The main theoretical framework of sustainability is the concept of sustainable development, coined by the World Commission on Environment and Development (WCED) and defined as: a process that meets the needs of the present without compromising the ability of future generations to meet their needs (Brundtland et al., 1987).

Since sustainable development deals with progress that does not compromise resources for the future, this concept can be understood from three perspectives, namely: (i) a type of growth that is environmentally friendly, (ii) a form of development that must be economically viable, and finally, (iii) a type of development that must advocate for social responsibility. Inspired by the tripartite character of sustainable development, in 1994 John Elkington defined a new theoretical framework called the Triple Bottom Line Theory (TBL or 3BL). This concept gained relevance in that it allowed the insertion of sustainability principles within business organizations (Elkington, 2001).

As Elkington (2001) pointed out, TBL can be understood as an extension of the sustainable development concept since it incorporates elements such as social equity, economic fundamentals and environmental responsibility. To summarize the essence of the TBL construct, Elkington suggested that the focus of this concept is centered around just three words: people, planet and profit. That is, it is a pluralistic approach to sustainability which dialogues directly with the reality of business organizations (Hindle, 2009). The first organization to adopt this 
concept in its internal processes was the oil company Shell, in 1997 (Elkington, 1997).

Among the attributes that make TBL stand out, it is noteworthy that, by encompassing the environmental, economic and social elements, this theory manages to address several elements of the same organization within a single, theoretical model (Janjua, Sarker, \& Biswas, 2020). Since 1997, several initiatives have been taken at the local, national and international levels, with the aim of addressing the different aspects of sustainability and the respective challenges that they present (Mebratu, 1998; Michelsen et al., 2016).

Beginning in the early 2000s, a strong global movement has put pressure on companies feel pressured to direct efforts towards the principles of the Triple Bottom Line Theory (Elkington, 2002). According to Zhou et al. (2018), this trend is explained by the mismatch between the growing demand for natural resources and the scarcity of several of these raw materials. This problem becomes even more evident when considering recent changes in the consumption profile of a portion of consumers, who have started to demand environmental certifications, products and/or services of the Cruelty-free type, for example, opposing unethical bodily production practices (Tang \& Zhou, 2012). In addition, the recent development of emerging markets, such as China and India, has put further pressure on the sustainability of organizations, as they impact the arrangement of production chains globally (Burki, Ersoy, \& Dahlstrom, 2018).

It is in this context of the scarcity of raw materials that the need to study the sustainability of organizations gains relevance. Thus, the success of organizational sustainability management processes depends on well-defined assessment models. Joseph Juran's famous phrase illustrates this issue: "whoever does not measure does not manage, whoever does not manage does not improve" (Conti et al., 2017). Therefore, measuring the performance of organizations regarding the use of productive resources is a topic that arouses the interest of local governments, the business sector and society in general (Stubbs \& Cocklin, 2008; Rehman et al., 2019).

\subsection{Objectives}

The general objective of the present article is to analyze the scientific production on the Triple Bottom Line Theory (TBL or 3BL). To this end, a bibliometric survey was carried out regarding 1386 publications, published between 1999 and 2020 and indexed in the Web of Science (WoS) database. Specifically, it is intended to:

(i) develop a descriptive study, showing the main sources of publication, authors, articles and countries that have publications on TBL;

(ii) present the evolution of academic production on this topic;

(iii) highlight the hot and cold areas of the academic debate about TBL; and,

(iv) establish a research agenda on the theme.

\section{Method}

The Web of Science (WoS) database (Reuters, 2019) was used to develop the present article. The choice is justified by two facts: (i) WoS has interfaces with the main bibliometric software, which allows the extraction of a significant set of bibliographic metadata, namely: abstracts, authors, cited references, countries, institutions and times cited; and, (ii) WoS is the main global repository for scientific research (Saadat \& Shaban, 2012). Following the choice of the database, the search parameters were established. The search parameters included the descriptor "Triple Bottom Line"; that is, all publications containing the expression "Triple Bottom Line" in their titles, abstracts or keywords were extracted.

All scientific papers indexed in the WoS database which satisfied the established criteria were selected. They totaled a sample universe of 1386 publications. Articles from conferences, journals and books, as well as technical reports, were analyzed. Metadata of work published between 1999 (first publication on the subject, based on the WoS) and 2020 (this is the last, most recent year) was extracted. Data collection took place on August 7, 2020.

Finally, the general aspect of these publications, including the evolution of research on TBL as well as a network of the keywords used most frequently in the selected articles, was verified. Metadata was analyzed using the VOSviewer ${ }^{\circledR}$ software (www.vosviewer.com) and the Bibliometrix ${ }^{\circledR}$ package, available for free in the R software (https://www.bibliometrix.org). It is noteworthy that VOSviewer ${ }^{\circledR}$ allows the creation of clusters and maps that aggregate the content of publications from various perspectives, such as keyword clouds (Van Eck \& Waltman, 2017).

\section{Results}

As stated above, the search for publications on Triple Bottom Line Theory, published between 1999 and 2020 
and indexed in the Web of Science database, yielded a total of 1386 items. These items were published in 735 different sources by 3373 authors. The publications on this topic consist of articles from journals, equivalent to $68 \%$ of the sample analyzed. There are conference articles, equivalent to $22 \%$ of the publications. The remaining publications, including books, editorials and gray materials, correspond to $10 \%$ of publications on TBL.

Figure 1 shows the ten main sources of publications on Triple Bottom Line Theory. Two journals, specifically, should be highlighted. They are: (i) Journal of Cleaner Production (it has 128 publications on this topic and its Journal Citation Reports (JCR) rating is equal to 7,246) and (ii) Sustainability (it has 91 publications and its JCR rating is equal to 2,576). These results are in line with the Bradford Bibliometric law, since most articles on TBL are concentrated in a few core journals (core publications). It is noteworthy that JCR is an annual publication of Clarivate Analytics, which provides information on academic journals, including impact factors. JCR was originally published as part of the Science Citation Index. As a distinct service, JCR is currently based on citations compiled from the Science Citation Index Expanded and the Social Sciences Citation Index. In each area of knowledge, higher JCR ratings for journals indicate that the impact generated by their articles is greater.

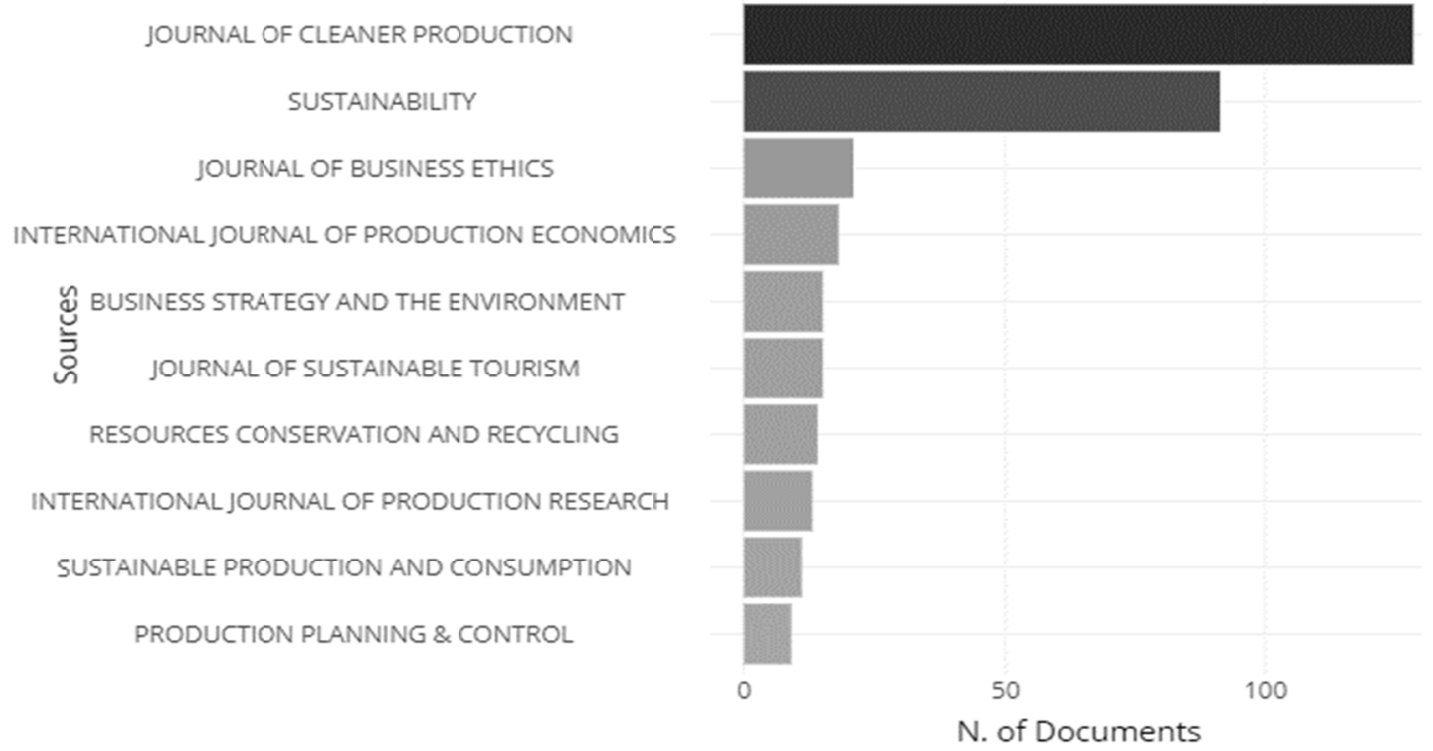

Figure 1. Main sources of publications on Triple Bottom Line Theory

Source: authors.

From the visualization of the main sources of publication, it becomes necessary to analyze, in greater depth, the main authors who publish on TBL. Table 1 shows the ranking of authors in terms of their numbers of publications on TBL, as well as the institutional affiliations of these authors. The results corroborate another Bibliometric law, Lotka's Law, since few researchers produce a large amount of research on the topic.

Table 1. Authors with more articles published on Triple Bottom Line Theory

\begin{tabular}{lllll}
\hline Ranking & Authors & Institution & Country & Articles \\
\hline 1 & SVENSSON G & Kristiania University College & Norway & 17 \\
2 & TSENG ML & Asia University & Taiwan & 13 \\
3 & KUCUKVAR M & Qatar University & Qatar & 10 \\
4 & WU KJ & National Taiwan University of Science and Technology & Taiwan & 10 \\
5 & HEWAGE K & The University of British Columbia & Canada & 9 \\
6 & PADIN C & Vigo Universty & Spain & 9 \\
7 & TATARI O & University of Central Florida & USA & 9 \\
8 & EDGEMAN R & Aarhus University, Shingo Institute, Southern Denmark University & Denmark & 7 \\
9 & FERRO C & Vigo Universty & Spain & 7 \\
10 & GOVINDAN K & University of Southern Denmark & Denmark & 7 \\
\hline
\end{tabular}

Source: authors. 
Following the analysis of the main researchers on Triple Bottom Line Theory, it is important to determine the main teaching and research institutions in this area. It should be noted that the three main institutions are, respectively: (i) The University of Queensland (with 24 articles), (ii) Arizona State University (with 22 articles), and (iii) University of São Paulo (USP) (with 18 articles). Table 2 presents details for these and other institutions.

Table 2. Main institutions that publish on Triple Bottom Line Theory

\begin{tabular}{llll}
\hline Ranking & University & Country & Articles \\
\hline 1 & The University of Queensland & Australia & 24 \\
2 & Arizona State University & USA & 22 \\
3 & Universidade de São Paulo (USP) & Brazil & 18 \\
4 & Asia University & Taiwan & 17 \\
5 & Universidade de Vigo & Spain & 16 \\
6 & Griffith University & Australia & 14 \\
7 & The Hong Kong Polytechnic University & China & 14 \\
8 & Monash University & Australia & 14 \\
9 & Dalian University of Technology & China & 13 \\
10 & Aarhus University & Denmark & 12 \\
\hline
\end{tabular}

Source: authors.

Figure 2 complements the results presented in Table 2. Figure 2 shows a strong concentration of publications in the United States, Brazil, China, Australia, India and countries in western Europe. It is noticed that there is a low rate of publication in African countries (except for South Africa).

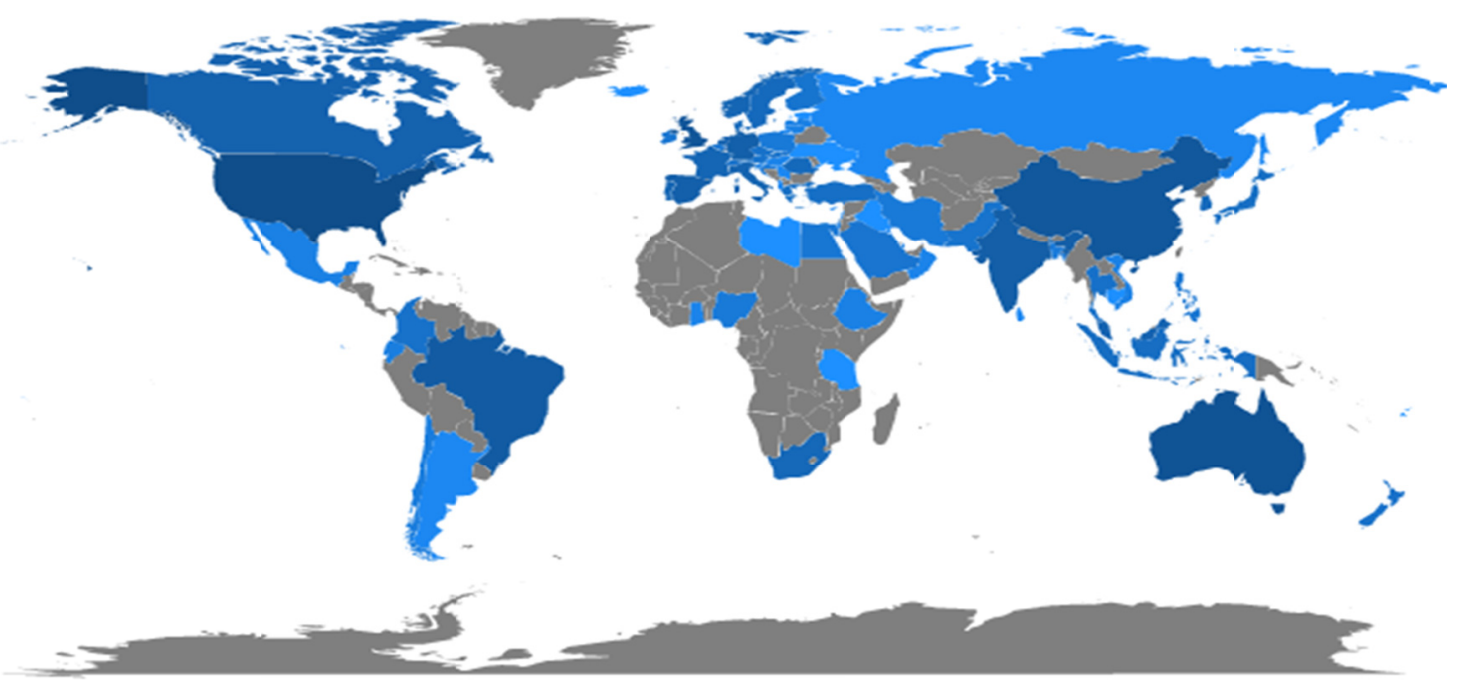

Figure 2. Countries with the greatest numbers of publications on Triple Bottom Line Theory

Source: authors.

Although the classification of countries is relevant for showing the number of publications on Triple Bottom Line Theory, this type of analysis nevertheless presents weaknesses. It is a purely quantitative portrait, and does not measure the quality of the studies carried out. To compensate for this, Figure 3 presents a new classification of countries, considering other attributes such as the total number of citations per country, as well as the average number of citations per article. Table 3 is configured on a color scale that ranges from green (higher values) to red (lower values). It is evident that the United States of America produces many articles and has many citations in total. However, the average number of citations per article is low. In contrast, Denmark is a country with few articles and a low number of citations. However, the average number of citations for each article is significantly high, which indicates a high degree of technical quality. It is reiterated that the present study took into consideration only publications indexed in WoS. Therefore, only the most relevant works were analyzed. Also, as shown in Table 3, high per-article citation rates can show where some of the seminal works on TBL were published. 


\begin{tabular}{lccc}
\hline Country & Total articles & Total citations & Citations per article (average) \\
\hline USA & 580 & 8976 & 33,744 \\
United Kingdom & 248 & 3647 & 32,562 \\
Australia & 315 & 3543 & 22,858 \\
Canada & 75 & 1956 & 43,467 \\
Germany & 100 & 1880 & 42,727 \\
Denmark & 37 & 1196 & 54,364 \\
China & 211 & 880 & 10,115 \\
Spain & 91 & 793 & 19,341 \\
Brazil & 142 & 748 & 10,841 \\
New Zeland & 18 & 591 & 45,462 \\
\hline
\end{tabular}

Figure 3. Classification of countries in terms of number of articles, total citations and average citations

Note. Legend: cells highlighted in green indicate the most significant values, cells highlighted in yellow indicate intermediate values, and cells highlighted in red indicate the lowest values observed.

Source: authors.

Following the descriptive analysis of these publications, it becomes necessary to study each of the main publications on Triple Bottom Line Theory in greater depth. Table 3 presents an initial synthesis of these publications, indicating which was the pioneer work, which was the work with the highest number of citations and, finally, which was the most recent work to be published on that topic. Table 3 also presents the title of each of these works and a summary of their theoretical contributions.

Table 3. Highlighted publications on Triple Bottom Line Theory

\begin{tabular}{|c|c|c|c|c|}
\hline & Authors & Citations & Title & Objectives \\
\hline $\begin{array}{l}\text { Pioneer } \\
\text { work }\end{array}$ & Elkington (1999) & 13 & $\begin{array}{l}\text { Petroleum in the } 21 \text { st } \\
\text { century: The triple bottom } \\
\text { line: implications for the } \\
\text { oil industry }\end{array}$ & $\begin{array}{l}\text { This work, focused on the oil sector, introduces the concept of the } \\
\text { Triple Bottom Line. The objective of the research was to present the } \\
\text { idea that companies and organizations should extend their agenda } \\
\text { beyond the objectives of economic prosperity, adopting a } \\
\text { three-dimensional approach to business, adding social justice and } \\
\text { environmental quality as new objectives in their agenda. }\end{array}$ \\
\hline $\begin{array}{l}\text { Most } \\
\text { cited }\end{array}$ & $\begin{array}{l}\text { Carter e Rogers } \\
\text { (2008) }\end{array}$ & 1257 & $\begin{array}{l}\text { A framework of } \\
\text { sustainable supply chain } \\
\text { management: moving } \\
\text { toward new theory }\end{array}$ & $\begin{array}{l}\text { The authors conduct a large-scale literature review and to introduce } \\
\text { the concept of sustainability. Specifically, they investigated the field of } \\
\text { supply chain management and demonstrated the relationships between } \\
\text { environmental, social and economic management. }\end{array}$ \\
\hline $\begin{array}{l}\text { Most } \\
\text { recent }\end{array}$ & $\begin{array}{l}\text { Arya, Srivastava e } \\
\text { Jaiswal (2020) }\end{array}$ & - & $\begin{array}{l}\text { Modelling environmental } \\
\text { and economic } \\
\text { sustainability of logistics }\end{array}$ & $\begin{array}{l}\text { The objective of this work is to explore the factors that affect } \\
\text { investment in technology to balance the environmental and economic } \\
\text { sustainability of logistics. }\end{array}$ \\
\hline
\end{tabular}

Source: authors.

Table 1 lists the top ten publications in terms of the number of citations, presenting each of the authors as well as the titles and objectives of the studies. It is noticed again that the results in Table 4 are indirectly related to Lotka's Law, since a limited number of authors have significant influence on the research on Triple Bottom Line Theory. This influence is seen not only in the number of published works but also, and especially, in the number of citations obtained by these publications. 
Table 4. The ten more cited articles on Triple Bottom Line

\begin{tabular}{|c|c|c|c|}
\hline Title of publication & Authors & Citations & Research object \\
\hline $\begin{array}{l}\text { A framework of sustainable } \\
\text { supply chain management: } \\
\text { moving toward new theory }\end{array}$ & $\begin{array}{l}\text { Carter e Rogers } \\
(2008)\end{array}$ & 1257 & $\begin{array}{l}\text { The authors perform a literature review to introduce the concept of } \\
\text { sustainability. Specifically, they investigated the field of supply chain } \\
\text { management and demonstrated the relationships between environmental, } \\
\text { social and economic management. }\end{array}$ \\
\hline $\begin{array}{l}\text { A literature and practice } \\
\text { review to develop sustainable } \\
\text { business model archetypes }\end{array}$ & $\begin{array}{l}\text { Bocken, Short, } \\
\text { Rana e Evans } \\
(2014)\end{array}$ & 776 & $\begin{array}{l}\text { This research seeks to develop a unifying research agenda, for which the } \\
\text { article presents archetypes of sustainable business models. These archetypes } \\
\text { seek to serve as examples for the innovation of the sustainable business } \\
\text { model. }\end{array}$ \\
\hline $\begin{array}{l}\text { Sustainable operations } \\
\text { management }\end{array}$ & $\begin{array}{l}\text { Kleindorfer, } \\
\text { Singhal e Van } \\
\text { Wassenhove } \\
(2005)\end{array}$ & 773 & $\begin{array}{l}\text { Through a literature review, the authors verified the evolution of research } \\
\text { related to the theme of sustainability. The research focused on a thorough } \\
\text { analysis of all the journals that published on this subject. }\end{array}$ \\
\hline $\begin{array}{l}\text { Sustainable supply chain } \\
\text { management: evolution and } \\
\text { future directions }\end{array}$ & $\begin{array}{l}\text { Carter e Easton } \\
(2011)\end{array}$ & 583 & $\begin{array}{l}\text { The objective of this article is to carry out a systematic review of the } \\
\text { sustainable supply chain management (SSCM) literature in the main } \\
\text { magazines of logistics and supply chain management, over a period of } 20 \\
\text { years. }\end{array}$ \\
\hline $\begin{array}{l}\text { Landscape sustainability } \\
\text { science: ecosystem services } \\
\text { and human well-being in } \\
\text { changing landscapes }\end{array}$ & $\mathrm{Wu}(2013)$ & 502 & $\begin{array}{l}\text { This article aims to: (1) elucidate the main definitions and concepts of } \\
\text { sustainability; (2) to examine the main definitions and concepts of } \\
\text { landscape sustainability, and (3) to propose a framework for the } \\
\text { development of a science of landscape sustainability. }\end{array}$ \\
\hline $\begin{array}{l}\text { Conceptualising sustainability } \\
\text { assessment }\end{array}$ & $\begin{array}{l}\text { Pope, Annandale e } \\
\text { Morrison-Saunders } \\
(2004)\end{array}$ & 466 & $\begin{array}{l}\text { This article seeks to provide some clarifications, reflecting on the different } \\
\text { approaches described in the literature as ways of assessing sustainability } \\
\text { and evaluating them in terms of their potential contributions to } \\
\text { sustainability. }\end{array}$ \\
\hline $\begin{array}{l}\text { A fuzzy multi criteria approach } \\
\text { for measuring sustainability } \\
\text { performance of a supplier } \\
\text { based on triple bottom line } \\
\text { approach }\end{array}$ & $\begin{array}{l}\text { Govindan, } \\
\text { Khodaverdi e } \\
\text { Jafarian (2013) }\end{array}$ & 408 & $\begin{array}{l}\text { This article explores sustainable supply chain initiatives and examines the } \\
\text { problem of identifying an effective model based on the TBL approach for } \\
\text { supply chain supplier selection operations, presenting a diffuse multicriteria } \\
\text { approach. }\end{array}$ \\
\hline $\begin{array}{l}\text { Getting to the bottom of "triple } \\
\text { bottom line" }\end{array}$ & $\begin{array}{l}\text { Norman e } \\
\text { Macdonald (2004) }\end{array}$ & 341 & $\begin{array}{l}\text { In this article, the authors critically examine the notion of "Triple Bottom } \\
\text { Line" and its measurement systems. }\end{array}$ \\
\hline $\begin{array}{l}\text { Sustainability-oriented } \\
\text { innovation of SMES: a } \\
\text { systematic review }\end{array}$ & $\begin{array}{l}\text { Klewitz e Hansen } \\
\text { (2014) }\end{array}$ & 334 & $\begin{array}{l}\text { This article provides a systematic review of the literature on } \\
\text { sustainability-oriented innovations (SOIs) for small and medium-sized } \\
\text { enterprises (SMEs). }\end{array}$ \\
\hline $\begin{array}{l}\text { Balancing priorities: } \\
\text { decision-making in sustainable } \\
\text { supply chain management }\end{array}$ & $\begin{array}{l}\text { Wu e Pagell } \\
\text { (2011) }\end{array}$ & 329 & $\begin{array}{l}\text { In this study, the authors attempt to answer the question: how do } \\
\text { organizations balance short-term profitability and long-term environmental } \\
\text { sustainability when making decisions about the supply chain under } \\
\text { conditions of uncertainty? }\end{array}$ \\
\hline
\end{tabular}

To present the evolution of academic interest in research related to Triple Bottom Line Theory, Figure 4 shows the number of publications on TBL according to the years of publication. There is an exponential increase in the number of publications as a function of the years. In addition, as shown in the upper right portion of Figure 3, it appears that $96.29 \%$ of the variations in the number of materials published on TBL can be explained by temporal variation. Given the above, the "quantitative presentation" of the relevance of TBL today is significant. 


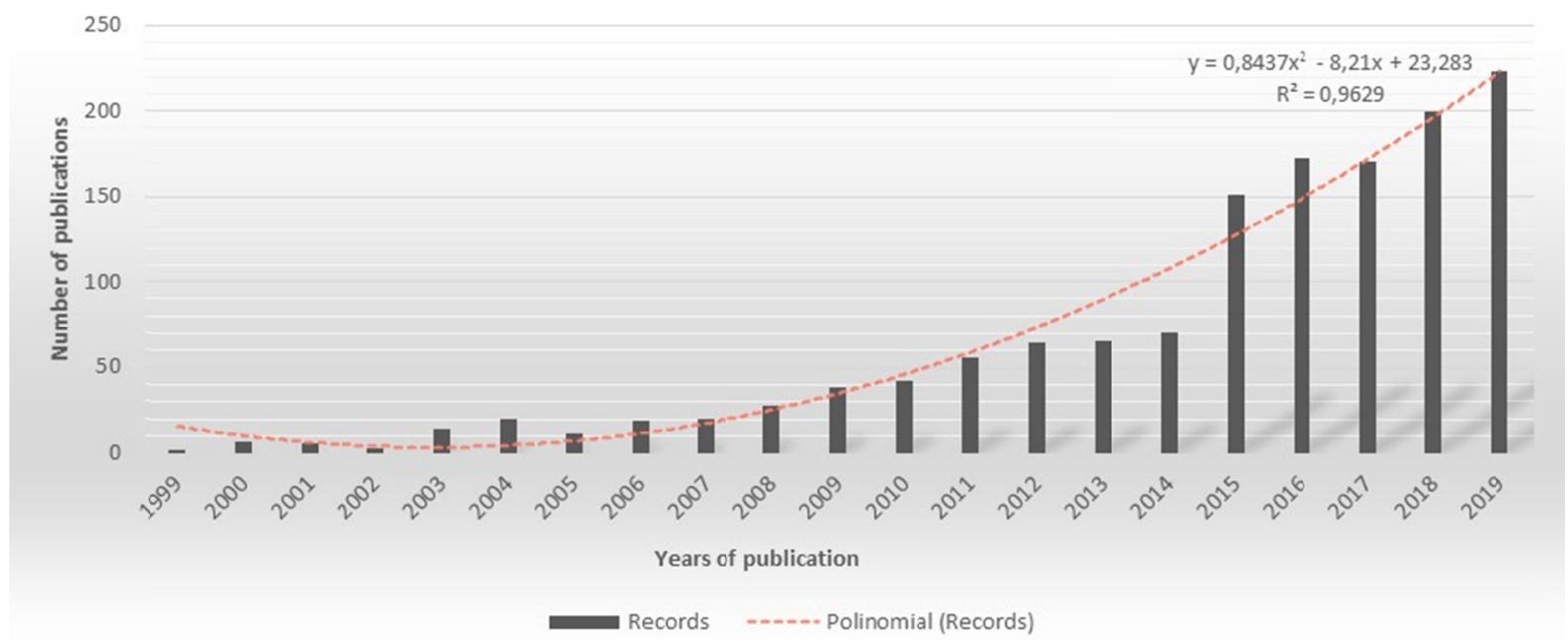

Figure 4. Time evolution of Triple Bottom Line Theory research

Note. data for the year 2020 is not included in Figure 4, as the total number of publications for this year has not yet been consolidated.

Source: authors. Based on all publications (articles, conferences and books that include the expression Triple Bottom Line in their titles, abstracts or keywords) published between the years 1999 and 2019, and indexed in the Web of Science (WoS) database.

Although TBL shows an increasing trend in the number of studies, it still has only approximately twenty years of existence. Therefore, because it is something new, it is assumed here that there is room for improvement and for the development of complementary theories that address some of its weaknesses. To show the main research gaps in this area, as well as to show the hot and cold areas of academic studies on TBL, Figure 5 presents the cluster formed by the main keywords used in studies on TBL.

As a selection criterion, only those keywords used at least twenty times in different studies, that is, those that have greater relevance in TBL research, were selected. It is noteworthy that the keywords were classified according to colors, where the yellow color denotes keywords used in recent studies. The current research on TBL has given outstanding importance to measuring the performance of organizations, both in the financial aspect as well as in the environmental sphere. In view of this, the present article is justified since the development of accurate models for measuring the performance of organizations (from the TBL perspective) is an object of current interest in the literature.

Figure 5 shows the main keywords linked to the scope of the present study, highlighted in red. They are: (i) financial performance, (ii) firm performance, (iii) environmental performance, (iv) competitive advantage, (v) sustainability reporting, (vi) decision-making, and (vii) sustainability assessment. 


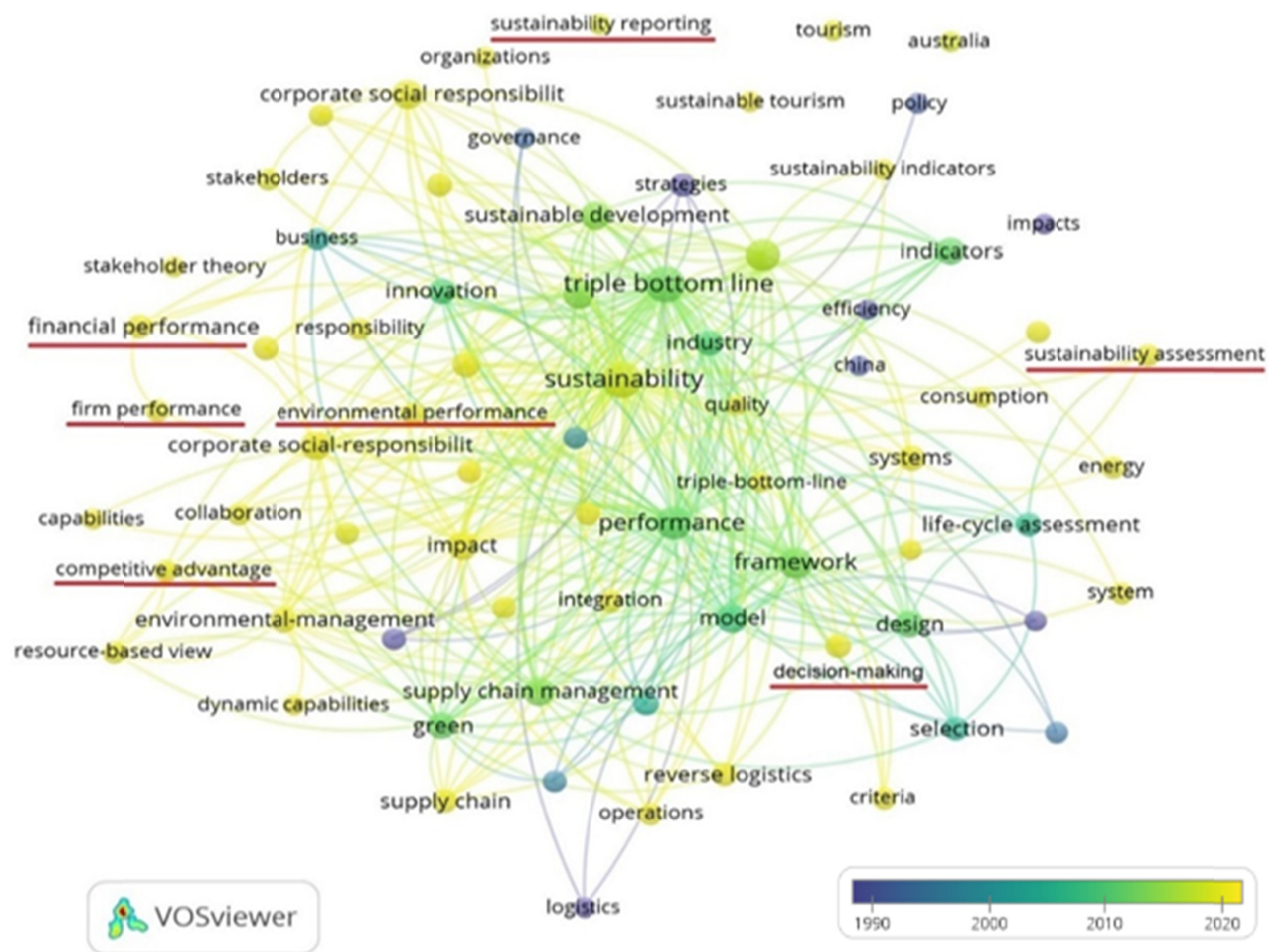

Figure 5. Time evolution in the use of the main keywords on Triple Bottom Line Theory

Note. data for the year 2020 is not included in Figure 5, as the total number of publications for this year has not yet been consolidated.

Source: authors. Based on all publications (articles, conferences and books that include the expression Triple Bottom Line in their titles, abstracts or keywords) published between the years 1999 and 2019, and indexed in the Web of Science (WoS) database. The graph considered only those keywords used at least twenty times in different studies.

We highlight here the close connection of the keyword "sustainable reporting" within the scope of TBL. In general terms, sustainability reports can be understood as a set of tools, used by companies of a sustainable nature and which aim to present their social, economic and environmental indicators with a higher degree of transparency (Ioannou \& Serafeim, 2017). Based on these reports, organizations define expectations for external and internal sustainable development. These expectations involve their employees, stakeholders, suppliers, customers and the local community in which they operate (Herremans, Nazari, \& Mahmoudian, 2016).

In this context, the information contained in the sustainability reports is remarkably relevant, since these reports can be used as the inputs for different models to measure organizational performance. Therefore, the quality of the sustainability reports is a topic that attracts the attention of both the academic and business communities. Information is one of the most valuable assets of the 21 st century, so companies that manage to systematize data from their production processes will be able to make strategic use of the information and, thus, to optimize the planning, monitoring and control of their activities.

Therefore, adequately measuring the performance of organizations is a relevant task, and some initiatives for this purpose have been presented in the literature. At the same time, due to its being an object of recent study in TBL research, many theoretical gaps still need to be filled. It is noteworthy that classic Data Envelopment Analysis (DEA) models have been used recurrently in studies on Triple Bottom Line Theory (Zhou et al., 2018; Chen, Su, \& Rogers, 2019).

\section{Discussion}

The scarcity of natural and environmental resources, characterized by the growing demand for raw materials 
from global supply chains, has led countries to intensify the design of sustainable public policies. In this context, to understand how to balance organizational responsibilities effectively in this "new era", the Triple Bottom Line sustainability theory emerges.

The present article contributes to the incipient debate about Triple Bottom Line Theory. It presents, in a pioneering way, a bibliometric study containing a comprehensive investigation of the main publications already carried out in the area. It is hoped that the present study will serve as a basis for researchers interested in the subject, as well as provide a roadmap for organizations working in the TBL context.

Due to their environmental, economic and social relevance, scientific publications on TBL have increased exponentially during the 21 st century, which indicates that it is an important area of research. In addition, the present article also looks at the hot and cold areas related to the TBL debate. It was found that topics such as the preparation of global sustainability reports, the development of performance measurement models (through the TBL pillars) and the construction of decision-making models are topics of current relevance in the literature. It should be noted that Data Envelopment Analysis (DEA) models have been used repeatedly for this purpose.

Finally, as a research agenda, a detailed study of decision-making models, aimed at measuring the environmental, economic and social performance of organizations, is recommended. It is suggested that the classic DEA models, especially their positive points as well as their main theoretical limitations, be analyzed. Therefore, it is believed that this research area, as it is still in its early stages, needs a more solid theoretical foundation. This will allow the adoption of assertive models for the management of organizations in the future, thus contributing to the rational use of scarce resources.

\section{Acknowledgments}

We thank the University FUMEC for technical support and the company Essencis, a partner in the development of this project.

\section{References}

Brundtland, G. H., Khalid, M., Agnelli, S., Al-Athel, S., \& Chidzero, B. J. N. Y. (1987). Our common future (p. 8). New York.

Burki, U., Ersoy, P., \& Dahlstrom, R. (2018). Achieving triple bottom line performance in manufacturer-customer supply chains: Evidence from an emerging economy. Journal of Cleaner Production, 197, 1307-1316. https://doi.org/10.1016/j.jclepro.2018.06.236

Chen, W. C., Su, C. P., \& Rogers, M. M. (2019). Measuring the performance of and tradeoffs within the triple bottom line. International Journal of Sustainable Transportation, 13(1), 24-35. https://doi.org/10.1080/15568318.2017.1419519

Chofreh, A. G., Goni, F., Shaharoun, A. M., \& Ismail, S. (2015). A review on sustainability transformation roadmaps using project management methodology. Advanced Science Letters, 21(2), 133-136. https://doi.org/10.1166/asl.2015.5841

Conti, D. D. (2017). Proposta e avaliação de indicadores de desempenho para gestão estratégica de unidades laboratoriais de instituição superior de ensino e pesquisa que impactam sobre a saúde humana. Master's thesis, Universidade Tecnológica Federal do Paraná.

De Carvalho, L. S., Stefanelli, N. O., Viana, L. C., Vasconcelos, D. D. S. C., \& Oliveira, B. G. (2020). Green supply chain management and innovation: a modern review. Management of Environmental Quality: An International Journal, 31(2). https://doi.org/10.1108/MEQ-12-2019-0283

Elkington, J. (1997). The triple bottom line. Environmental Management: Readings and Cases, 2.

Elkington, J. (2001). The triple bottom line for 21st century business (pp. 20-43). The Earthscan reader in business and sustainable development.

Elkington, J. (2002). The triple bottom line of the 21st century. Oxford Press, Oxford.

He, B., Li, F., Cao, X., \& Li, T. (2020). Product sustainable design: a review from the environmental, economic, and social aspects. Journal of Computing and Information Science in Engineering, 20(4). https://doi.org/10.1115/1.4045408

Herremans, I. M., Nazari, J. A., \& Mahmoudian, F. (2016). Stakeholder relationships, engagement, and sustainability reporting. Journal of Business Ethics, 138(3), 417-435. https://doi.org/10.1007/s10551-015-2634-0 
Hindle, T. (2009). Triple bottom line. The Economist, 17.

Ioannou, I., \& Serafeim, G. (2019). The consequences of mandatory corporate sustainability reporting. In The Oxford Handbook of Corporate Social Responsibility. https://doi.org/10.1093/oxfordhb/9780198802280.013.20

Janjua, S. Y., Sarker, P. K., \& Biswas, W. K. (2020). Development of triple bottom line indicators for life cycle sustainability assessment of residential bulidings. Journal of Environmental Management, 264, 110476. https://doi.org/10.1016/j.jenvman.2020.110476

Lowitt, E. (2011). The future of value: How sustainability creates value through competitive differentiation. John Wiley \& Sons.

Matopoulos, A., Barros, A. C., \& van der Vorst, J. J. (2015). Resource-efficient supply chains: a research framework, literature review and research agenda. Supply Chain Management: An International Journal, 20(2). https://doi.org/10.1108/SCM-03-2014-0090

Mebratu, D. (1998). Sustainability and sustainable development: Historical and conceptual review. Environmental Impact Assessment Review, 18(6), 493-520. https://doi.org/10.1016/S0195-9255(98)00019-5

Michelsen, G., Adomßent, M., Martens, P., \& von Hauff, M. (2016). Sustainable development—background and context. In Sustainability science (pp. 5-29). Springer, Dordrecht. https://doi.org/10.1007/978-94-017-7242-6_2

Rehman, S., Sami, A., Haroon, A., \& Irfan, A. (2019). Impact of Sustainable Leadership Practices on Public Sector Organizations: A Systematic Review of Past Decade. Journal of Public Value and Administration Insights, 2(3), 1-5. https://doi.org/10.31580/jpvai.v2i3.927

Reuters, T. (2019). ISI Web of Science. New York: Thomson Reuters.

Saadat, R., \& Shabani, A. (2012). Investigating the citations received by journals of Directory of Open Access Journals from ISI Web of Science's articles. International Journal of Information Science and Management (IJISM), 9(1), 57-74.

Stubbs, W., \& Cocklin, C. (2008). Conceptualizing a "sustainability business model". Organization \& Environment, 21(2), 103-127. https://doi.org/10.1177/1086026608318042

Tang, C. S., \& Zhou, S. (2012). Research advances in environmentally and socially sustainable operations. European Journal of Operational Research, 223(3), 585-594. https://doi.org/10.1016/j.ejor.2012.07.030

Van Eck, N. J., \& Waltman, L. (2017). Citation-based clustering of publications using CitNetExplorer and VOSviewer. Scientometrics, 111(2), 1053-1070. https://doi.org/10.1007/s11192-017-2300-7

Zhou, H., Yang, Y., Chen, Y., \& Zhu, J. (2018). Data envelopment analysis application in sustainability: The origins, development and future directions. European Journal of Operational Research, 264(1), 1-16. https://doi.org/10.1016/j.ejor.2017.06.023

\section{Copyrights}

Copyright for this article is retained by the author, with first publication rights granted to the journal.

This is an open-access article distributed under the terms and conditions of the Creative Commons Attribution license (http://creativecommons.org/licenses/by/4.0/). 